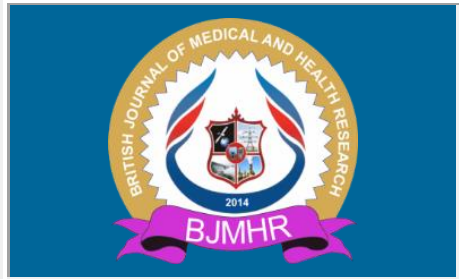

\title{
BJMHR
}

British Journal of Medical and Health Research

Journal home page: www.bjmhr.com

\section{Protein $\mathrm{C}$ and S Deficiency Presenting as Right Sigmoid Sinus Thrombosis in Young Female: A Case Report and Review.}

\section{Shah Archie*, Gill Rooppreet, Kapadiya Sajni, Lakhani Jitendra \\ Department of medicine, Smt.B.K.Shah Medical Institute\& Research Centre, Sumandeep Vidyapeeth, Vadodara-391760.}

\begin{abstract}
Cerebral sinus venous thrombosis represents $0.5-3 \%$ of all type of stroke affecting predominantly young people mainly female of reproductive age group. We are reporting a case of 32 year old female patient with no risk factors who presented to us with newly detected diabetes mellitus, left upper limb monoparesis which on investigating patient had right sigmoid sinus thrombosis due to protein $\mathrm{c}$ and protein s deficiency. The reporting and discussion is highly important as it adds to already existing knowledge and helps in making wise decision regarding evaluation of such patients. Long term anticoagulants and prevention of mentioned risk factors is main goal of treatment in these patients.
\end{abstract}

Keywords: young female, cerebral sinus thrombosis, protein $\mathrm{C}$, protein $\mathrm{S}$ 


\section{INTRODUCTION}

Stroke in young is increasing with high rates of morbidity. Cerebral sinus venous thrombosis (CSVT) is a rare vascular cause of acute neurological events. Cerebral sinus venous thrombosis represents $0.5 \%-3 \%$ of all the types of stroke ${ }^{1}$.Cerebral venous sinus thrombosis affects predominantly younger people ${ }^{2}$. It is estimated that incidence of cerebral sinus venous thrombosis is 3-4 per million for adults ${ }^{3}$.Female are three times more commonly affected than males with majority of female belong to child bearing age group ${ }^{4}$.The prevalence of peripartum cerebral venous thrombosis is 11.5 cases per 100,000 deliveries of pregnant female ${ }^{5}$.

The International Study on Cerebral vein and Dural Sinus thrombosis determine the prevalence of CSVT in different sinuses - Transverse sinus (86\%), superior sagittal sinus (62\%), straight sinus (18\%), cortical veins (17\%), jugular veins (12\%), sigmoid sinus (9\%), vein of Galen and internal cerebral vein $(17 \%)^{4}$.

The prevalence of protein $\mathrm{C}$ deficiency is 0.6 to $1.0 \%$ in patients with venous thromboembolism ${ }^{6}$. The prevalence of protein $\mathrm{S}$ deficiency in patients with history of recurrent thrombosis or with family history of thrombosis is 3-6 \% . Protein $\mathrm{S}$ deficiency is rare in healthy adults without any abnormalities.

We are reporting a case of 32 year old female having with newly detected diabetes mellitus having protein $\mathrm{C}$ and protein $\mathrm{S}$ deficiency who presented with right sigmoid sinus thrombosis.

\section{CASE REPORT:}

A 32 year old right handed female presented with complain of unilateral, right fronto-parietal region headache since 6 months and 1 episode of generalized tonic seizure followed by left upper limb weakness 2 days prior to presentation.

Patient had no history of spontaneous abortion, oral contraceptive pills consumption, trauma, hemoglobinopathies and no recent pregnancy and infections. No family history of thromboembolic events.

She was admitted and on her examination, patient was obtunded but arousable . Her vitals on admission - BP - 140/90 mmHg, HR - 100 beats/minute. Her BMI was 29. On neurological examination, she had left upper limb monoparesis, plantars were bilateral flexors with supranuclear facial and hypoglossal nerve palsy with right side gaze deviation (left conjugate gaze palsy ) was present and pupils were bilaterally equally reacting to light. Her other systems examinations were normal.

On clinical suspicion of vascular event in right cerebral hemisphere, MRI with MR angiogram and MR venogram was done which revealed right sigmoid sinus thrombosis (figure 1A) and venous infract with haemorrhagic transformation in right parietal region (Figure 2). On further investigation patient was diagnosed with newly detected diabetes mellitus type II .Her HbA1C 
was 9.9\%,c-peptide levels were raised .Anti-GAD antibody was negative ,HPLC for sickle haemoglobinopathy was negative. Homocystiene levels were normal, patient was having hyperlipidaemia (cholesterol of 205 and triglyceride of 317) ANA profile was negative. Antiphospholipid antibody (APLA) was negative. Urine routine and micro was negative for albumin.

She was further investigated with thrombotic profile where her protein $\mathrm{C}$ was $41.5 \%$ ( normal 65-140) and protein $\mathrm{S}$ was $42.3 \%$ ( normal 60.1-113.6) and thrombin III level were within normal limit.

Patient was started on injectable conventional heparin therapy. Patient was also started on antiepileptic therapy, injectable mannitol and injectable basal/bolus regular insulin. Within two days she started showing improvement. Her consciousness improved and there was improvement in tone and power of left upper limb. Patient was discharged with warfarin therapy and continuous follow up of patient was done. No any new symptoms developed.

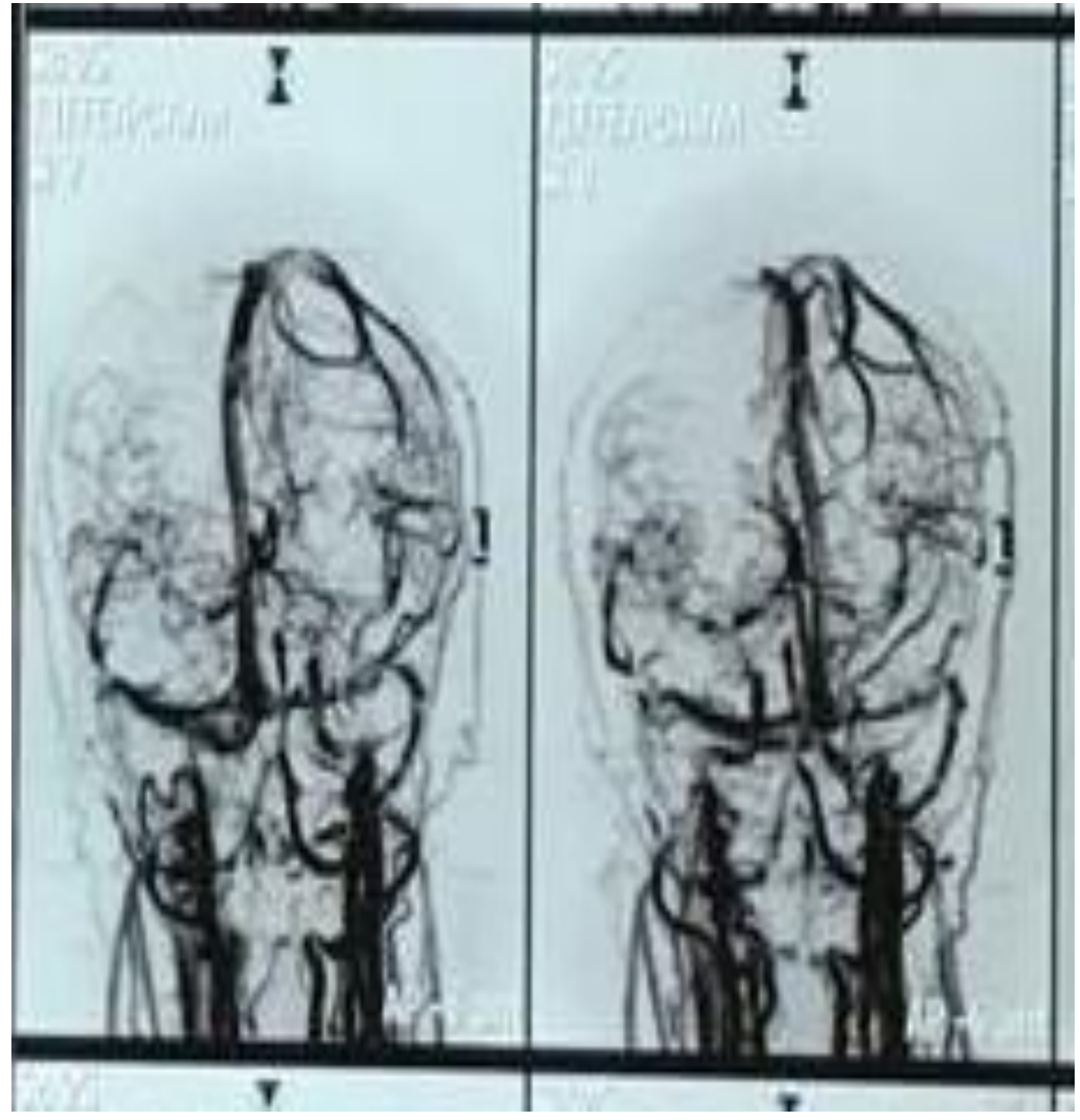

(A)

Figure 1: Right sigmoid sinus thrombosis 


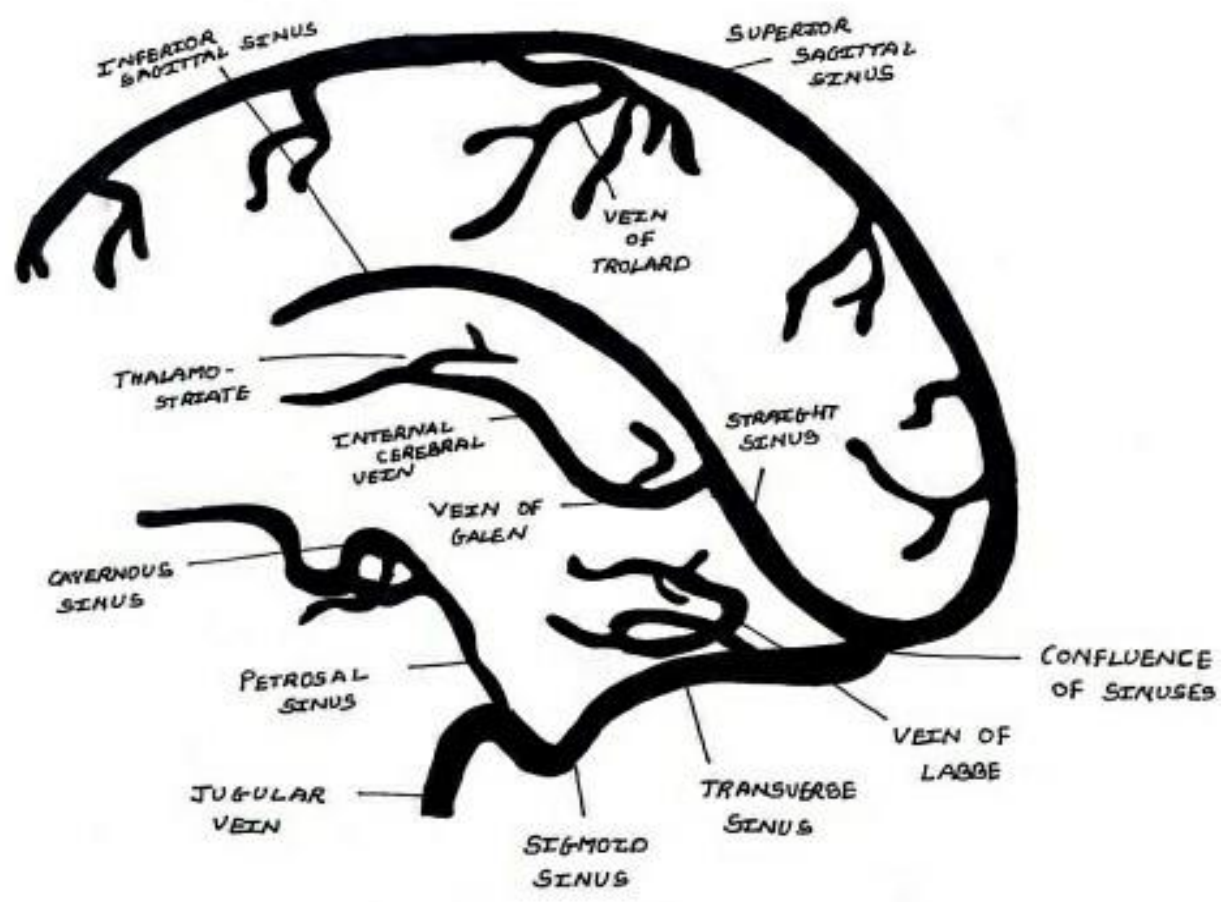

Figure 1B: Normal Dural sinus Anatomy

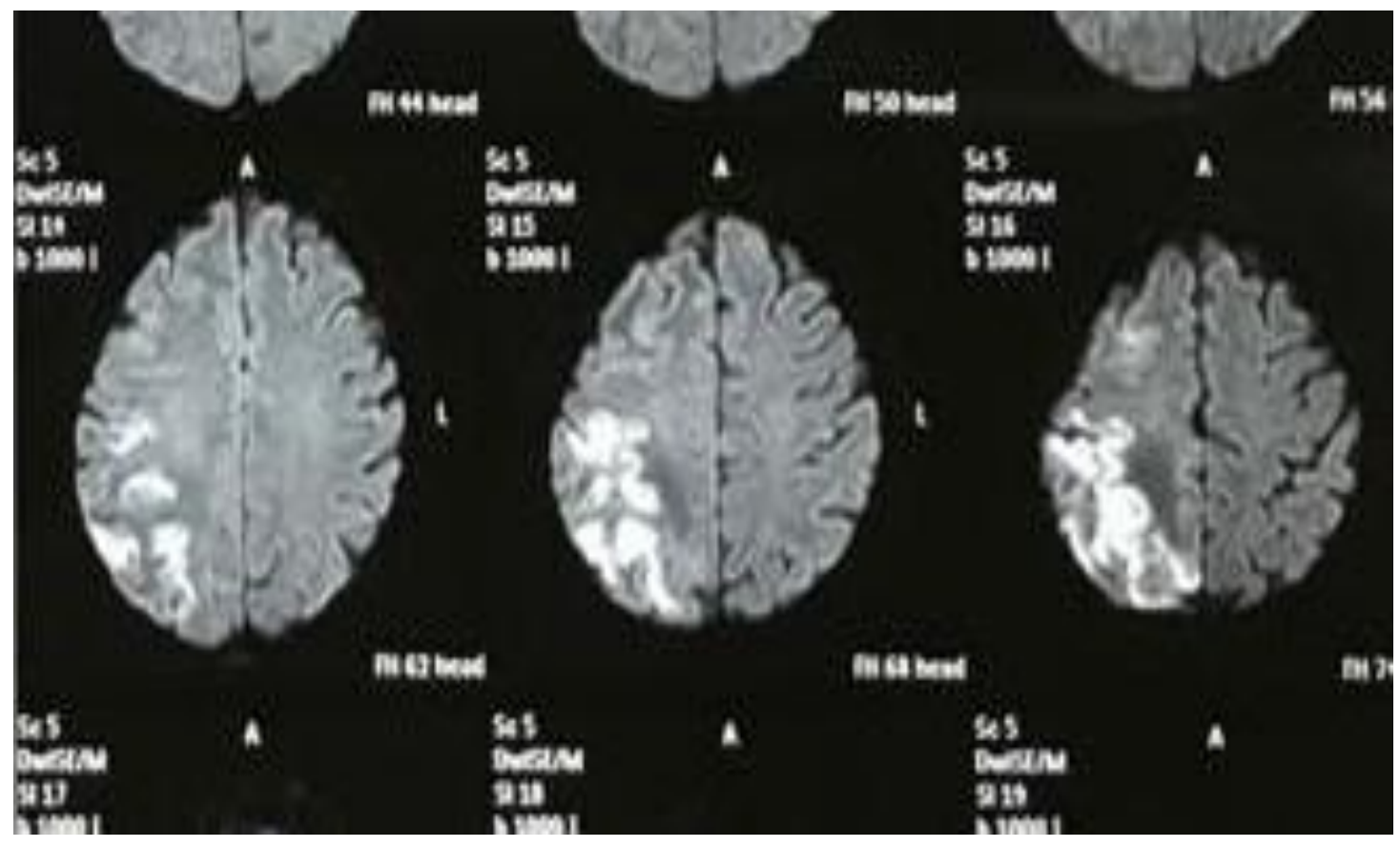

Figure 2: Right parietal infract with haemorrhagic transformation.

\section{DISCUSSION:}

The nature has bestowed human beings with naturally occurring anticoagulation system which is often less spoken about. A balance between procoagulants and anticoagulants has been maintained under normal physiological conditions. The most important naturally occurring anticoagulants are protein $\mathrm{C}$, protein $\mathrm{S}$ and Anti thrombin III $^{8}$. The quantitative and qualitative deficiencies of these naturally occurring anticoagulants can be either inherited or acquired ${ }^{9}$. 
Inherited deficiencies are very less common and present in early childhood. The case of young female we described here, had protein $\mathrm{C}$ and $\mathrm{S}$ deficiency which became evident when she developed a venous thrombotic event involving dural venous sinuses.

Protein $\mathrm{C}$ and $\mathrm{S}$ deficiency can lead to venous thromboembolism at any site, most commonly found in the deep veins of the leg, mesenteric veins, and pulmonary embolism but other sites can also be affected like dural venous sinuses, cerebral veins, portal vein ${ }^{10}$. It has been found that the risk of thrombosis with heterozygous protein $\mathrm{C}$ deficiency is seven-fold $\operatorname{high}^{11}$. However it is difficult to estimate the risk of thrombotic events in individuals with protein $\mathrm{C}$ and $\mathrm{S}$ deficiency but it is of utmost importance to find and manage modifying factors that can be contributary like family history of venous thromboembolic events, prolonged immobility, oral hormonal contraceptive use, pregnancy, parturition and surgery ${ }^{12}$. It has been observed that the risk of thrombosis in such individuals is 1 per 100 patients-years ${ }^{12}$. The deficiency of protein $\mathrm{C}$ and $\mathrm{S}$ can be suspected in those who present with recurrent venous thrombosis, thrombosis in an unusual vascular bed i.e; portal, hepatic, mesenteric and cerebral, thrombosis at a young age ( $<50$ years), strong family history of venous thromboembolism , and/or warfarin-induced skin necrosis ${ }^{13}$. The diagnosis can be made by documenting low protein $\mathrm{C}$ levels. It has been observed that the first episode of venous thrombosis in such patients in spontaneous in $2 / 3^{\text {rd }}$ of cases while in remaining cases the risk factors as described above are present. In a study by Bovill, Edwin G., et al. , a family with propensity of increased thromboembolic events was investigated in New England kindred, evaluating 184 of the 411 surviving members of the pedigree, 46 members determined to be deficient, out of which 13 had thrombotic events ${ }^{14}$.

Stroke in young patients attracts barrage of diagnostic tests, aiming at looking for underlying thrombophilic states. As observed in the case reported above, a venous infarct in young female otherwise healthy, with no risk factors, prompted us to investigate for although uncommon but important cause for increased hypercoaguable state ie; protein C, S and AT III deficiency. Protein $\mathrm{C}$ is a Vitamin $\mathrm{K}$ dependents plasma protein that acts as an anticoagulant, degrades factor $\mathrm{V}$ and inactivates factor VIII, facilitating thrombolysis ${ }^{8}$. Protein $\mathrm{S}$ is a cofactor for protein $\mathrm{C}$. The combined deficiencies have been reported and their relevance for venous thrombosis is well established ${ }^{15}$. Not only cerebral venous infarcts, but these deficiencies could also cause arterial thrombotic ischemic infarcts, as described in a case report by Patel, Munna Lal et al. - 'combined deficiency of protein $\mathrm{C}$ and $\mathrm{S}$ : Ischemic stroke in young individuals' 16 implying that deficiency of both anticoagulant factors in same patient may predispose strongly for arterial and venous thrombosis.

Cerebral sinus venous thrombosis( CSVT) is a rare form of venous thrombosis and affects predominantly younger individuals with female preponderance $-3: 1^{17}$. The leading causes 
currently for CSVT are aseptic whereas in pre-antibiotic era, septic causes were found most common causes ${ }^{18}$. Among infective causes it was found as complication of cerebral abscess, subdural empyema, meningitis, regional infections like otitis, sinusitis, orbital cellulitis, tonsillitis, dental infection, stomatitis, cutaneous cellulitis and Bacterial septicaemia, endocarditis, typhoid, tuberculosis, malaria, trichinosis, toxoplasmosis, Cryptococcus, aspergillosis ${ }^{18}$.There is high proportion of anastomosis, so it is difficult to diagnose in cases of occlusion. Dural sinuses are divided into posterior superior and anterior inferior groups. The sigmoid sinus and transverse sinus are lateral sinuses which are part of group of posterior superior sinuses ${ }^{19}$. The transverse sinus thrombosis is most common site $(86 \%)$ whereas sigmoid sinus thrombosis is seen in only $9 \%$ of $\mathrm{CSVT}^{19}$.

The presentation of cerebral sinus thrombosis occurs in three forms - Acute form ( $<48$ hours ) which occurs in $30 \%$ of populations, sub acute form (48 hours to 30 days) which occurs in $50 \%$ of population ,chronic form (30 days to 6 months ) which occurs in $20 \%$ of populations ${ }^{17}$. There are 4 Clinical patterns of CSVT presentation - Focal syndrome: presence of focal signs associated with headache, seizures or changes in mental state, Isolated Intracerebral haemorrhage with headache, nausea, vomiting and papilledema, Diffuse sub-acute encephalopathy with changes in mental state and cavernous sinus syndrome -painful ophthalmoplegia, chemosis, proptosis ${ }^{20}$. There have been two mechanisms which contribute to the clinical manifestations of cerebral venous thrombosis. The thrombosis of cerebral veins leads to increase in venular and capillary pressure. Cerebral sinus occlusion leads to disruption of arachnoid granulations leading to decrease in CSF absorption. Both of these leads to increase in intracranial pressure. Increase in intracranial pressure for longer time leads to disruption of blood brain barrier, leading to leakage of capillary components producing cytotoxic and vasogenic oedema and parenchymal tissue damage ${ }^{18}$.

Cerebral sinus thrombosis is unusual form of stroke affecting young populations mainly female of reproductive age group. The reporting and discussion of such cases is highly important as it adds to the already existing knowledge and helps in making wise decisions regarding evaluation of such patients. It is the form of stroke with varied clinical presentation most common being headache. The diagnosis is mainly done by CT and MRI/MRV and if other imaging modalities fail then cerebral angiography can be done. And investigating for protein $\mathrm{C}$ and S deficiency in such patients who are highly suspected is recommended. Long term anticoagulation therapy and prevention of above mentioned risk factors is main line of treatment in these patients. Anticoagulants are not contraindicated even if there is haemorrhagic transformation in these patients. The chances of recurrences are high in these patients depending upon the cause of the thrombosis. Early diagnosis is often delayed due to nonspecific patterns of presentations. 


\section{CONCLUSION:}

The cerebral venous sinuses thrombosis is a treatable condition, commonly seen in younger females, identifying underlying cause and risk factors becomes critical for prevention of future thromboembolic events.

\section{REFERENCES:}

1. Bousser MG, Ferro JM. Cerebral venous thrombosis: an update. The Lancet Neurology. 2007 Feb 1;6(2):162-70.

2. Ruiz-Sandoval JL, Chiquete E, Bañuelos-Becerra LJ, Torres-Anguiano C, GonzálezPadilla C, Arauz A, León-Jiménez C, Murillo-Bonilla LM, Villarreal-Careaga J, Barinagarrementería F, Cantú-Brito C. Cerebral venous thrombosis in a Mexican multicenter registry of acute cerebrovascular disease: the RENAMEVASC study. Journal of stroke and cerebrovascular diseases. 2012 Jul 1;21(5):395-400.

3. Stam J. Thrombosis of the cerebral veins and sinuses. New England Journal of Medicine. 2005 Apr 28;352(17):1791-8.

4. Ferro JM, Canhão P, Stam J, Bousser MG, Barinagarrementeria F. Prognosis of cerebral vein and dural sinus thrombosis: results of the International Study on Cerebral Vein and Dural Sinus Thrombosis (ISCVT). Stroke. 2004 Mar 1;35(3):664-70.

5. Lanska DJ, Kryscio RJ. Risk factors for peripartum and postpartum stroke and intracranial venous thrombosis. Stroke. 2000 Jun;31(6):1274-82.

6. Tait RC, Walker ID, Reitsma PH, et al. Prevalence of protein C deficiency in the healthy population. J Med Assoc Thai. 2005;88(suppl 4):S249-S254.

7. Brouwer JL,Lijfering WM,Ten Kate MK, Kluin-Nelemans HC, Veeger NJ, vander Meer J. High long term absolute risk of recurrent venous thromboembolism in patients with hereditary deficiencies of prtein S, protein C or antithrombin. Thromb Haemost. 2009Jan.101(1):93-9.

8. Clouse LH, Comp PC. The regulation of hemostasis: the protein C system. New England Journal of Medicine. 1986 May 15;314(20):1298-304.

9. Reitsma PH, Bernardi F, Doig RG, Gandrille S, Greengard JS, Ireland H, Krawczak M, Lind B, Long GL, Poort SR, Saito H. Protein C deficiency: a database of mutations, 1995 update. Thrombosis and haemostasis. 1995;73(05):876-89.

10. Wintzen AR, Broekmans AW, Bertina RM, Briet E, Briet PE, Zecha A, Vielvoye GJ, Bots GT. Cerebral haemorrhagic infarction in young patients with hereditary protein C deficiency: evidence for" spontaneous" cerebral venous thrombosis. Br Med J (Clin Res Ed). 1985 Feb 2;290(6465):350-2. 
11. Tait RC, Walker ID, Reitsma PH, Islam SI, McCall F, Poort SR, Conkie JA, Bertina RM. Prevalence of protein $\mathrm{C}$ deficiency in the healthy population. Thrombosis and haemostasis. 1995;73(01):087-93.

12. Martinelli I, Mannucci PM, De Stefano V, Taioli E, Rossi V, Crosti F, Paciaroni K, Leone G, Faioni EM. Different risks of thrombosis in four coagulation defects associated with inherited thrombophilia: a study of 150 families. Blood, The Journal of the American Society of Hematology. 1998 Oct 1;92(7):2353-8.

13. Pabinger I, Allaart CF, Hermans J, Briet E, Bertina RM, Protein C Transmitter Study Group. Hereditary protein C-deficiency: laboratory values in transmitters and guidelines for the diagnostic procedure report on a study of the SSC subcommittee on protein C and protein S. Thrombosis and haemostasis. 1992;68(10):470-4.

14. Bovill EG, Bauer KA, Dickerman JD, Callas P, West B. The clinical spectrum of heterozygous protein $\mathrm{C}$ deficiency in a large New England kindred.

15. Colman RW, editor. Hemostasis and thrombosis: basic principles and clinical practice. Lippincott Williams \& Wilkins; 2006.

16. Patel ML, Sachan R, Seth G. Combined deficiency of proteins C and S: ischaemic stroke in young individuals. Case Reports. 2013 Dec 12; 2013:bcr2012008016.

17. Ferro JM, Canhão P, Stam J, Bousser MG, Barinagarrementeria F. Prognosis of cerebral vein and dural sinus thrombosis: results of the International Study on Cerebral Vein and Dural Sinus Thrombosis (ISCVT). Stroke. 2004 Mar 1;35(3):664-70

18. Guenther G, Arauz A. Cerebral venous thrombosis: a diagnostic and treatment update. Neurología (English Edition). 2011 Oct 1;26(8):488-98.

19. Moscote-Salazar L, Alcala-Cerra G, Alvis-Miranda H, Castellar-Leones S. Cerebral sinus venous thrombosis. J Neurosci Rural Pract. 2013;4(4):427.

20. Saposnik G, Barinagarrementeria F, Brown Jr RD, Bushnell CD, Cucchiara B, Cushman M, Deveber G, Ferro JM, Tsai FY. Diagnosis and management of cerebral venous thrombosis: a statement for healthcare professionals from the American Heart Association/American Stroke Association. Stroke. 2011 Apr;42(4):1158-92.

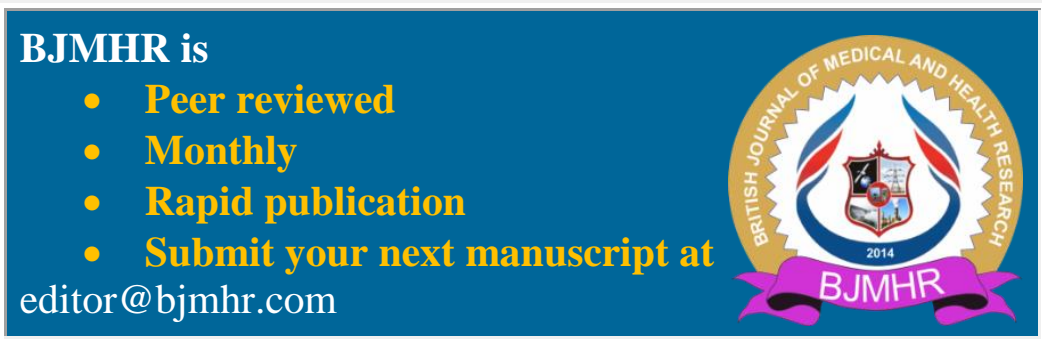

